\title{
Direct access to pyrido/pyrrolo[2,1-b]quinazolin-9(1H)-ones through silver-mediated intramolecular alkyne hydroamination reactions
}

\author{
Hengshuai Wang ${ }^{1}$, Shengchao Jiao ${ }^{1,2}$, Kerong Chen ${ }^{1}$, Xu Zhang ${ }^{1}$, Linxiang Zhao ${ }^{2}$, \\ Dan Liu ${ }^{2}$, Yu Zhou ${ }^{* 1}$ and Hong Liu ${ }^{1}$
}

\author{
Full Research Paper

\section{Address:} \\ ${ }^{1}$ CAS Key Laboratory of Receptor Research, Shanghai Institute of \\ Materia Medica, Chinese Academy of Sciences, 555 Zuchongzhi \\ Road, Shanghai 201203, P. R. China and ${ }^{2}$ Shenyang Pharmaceutical \\ University, 103 Wenhua Road, Shengyang 110016, P. R. China

\author{
Beilstein J. Org. Chem. 2015, 11, 416-424. \\ doi:10.3762/bjoc. 11.47 \\ Received: 21 November 2014 \\ Accepted: 02 March 2015 \\ Published: 30 March 2015 \\ Associate Editor: J. Aubé \\ (c) 2015 Wang et al; licensee Beilstein-Institut. \\ License and terms: see end of document.
}

\begin{abstract}
We report a synthetic methodology for the construction of the fused heterocyclic compounds pyrido[2,1- $b]$ quinazolin- $9(1 H)$-ones and pyrrolo[2,1-b]quinazolin-9(1H)-ones through an AgOTf-catalyzed intramolecular alkyne hydroamination reaction. The methodology is applicable to a wide scope of substrates and produces a series of fused quinazolinone heterocycles in good to excellent yields.
\end{abstract}

\section{Introduction}

Quinazolinone is a core skeleton for naturally existing phytochemicals. They were extracted from a variety of plant families. Among the quinazolinone derivatives, such as the pyrrolo[2,1$b$ ]quinazolinone alkaloids, are a multitude of biomedically active substances [1,2]. For example, deoxyvasicione (1), 8-hydroxydeoxyvasicinone (2), compound 73/602 (3), mackinazolinone (4) and vasicinone (5) have been proven to act as bronchodilatory, anti-inflammatory, antimicrobial and antidepressant agents (Figure 1) [2-8].

A variety of approaches have been employed to synthesize deoxyvasicione (1) and its derivatives, e.g., the $\mathrm{Pd}(\mathrm{OAc})_{2}-$ catalyzed carbonyl-insertion reaction [7], the cycloaddition of anthranilic acid iminoketene to a methyl butyrolactam through a sulfinamide anhydride intermediate [9], the intramolecular azaWittig reaction with an azide substrate [10], and the cycloaddition of anthranilamide [11]. For the synthesis of vasicinone (5), deoxyvasicinone was subjected to a free-radical bromination using NBS and the subsequent treatment with $\mathrm{NaOAc} / \mathrm{AcOH}$ as an acetoxylation reagent [12]. However, for most of these synthetic strategies harsh reaction conditions are a necessity, produce unstable sulfonamide anhydride intermediates [2,13], which are dangerous substrates bearing an azide group, and require a high reaction temperature and a long reaction time 
<smiles>[R]c1cc([R1])c2nc3n(c(=O)c2c1)CCC3</smiles>

$R^{1}=R^{2}=H$, deoxyvasicione (1)

$\mathrm{R}^{1}=\mathrm{OH}, \mathrm{R}^{2}=\mathrm{H}, 8$-hydroxydeoxyvasicinone (2)

$\mathrm{R}^{1}=\mathrm{H}, \mathrm{R}^{2}=\mathrm{OCH}_{3}$, compound 73/602 (3)<smiles>[R]c1cc([R1])c2nc3n(c(=O)c2c1)CCCC3</smiles>

$\mathrm{R}^{1}=\mathrm{R}^{2}=\mathrm{H}$

mackinazolinone (4)<smiles>O=c1c2ccccc2nc2n1CCC2O</smiles>

vasicinone (5)

Figure 1: Selected structures of fused quinazolinones.

$[2,10]$. Recently, transition metal catalyzed hydroamination of alkynes [14-26], alkenes [15,27-31] and dienes [32,33] has been widely studied for the construction of heterocycles. We have reported on a highly efficient gold/silver-catalyzed intramolecular hydroamination of terminal alkynes in water for the synthesis of fused tricyclic xanthenes [34]. On the basis of this methodology, we have also afforded two fused benzimidazoles through silver-catalyzed intramolecular hydroamination from readily available starting materials with a long-chain alkyne $[35,36]$. Motivated by the unique structural properties and the biological activities characteristic of the vasicinone type alkaloids, we extended our work in this direction by elaborating the synthesis of fused quinazolinone derivatives. Herein, we present our recent findings of the synthesis of fused pyrrolo[2,1b] quinazolin-9 $(1 H)$-ones by a silver-mediated chemoselective and regioselective intramolecular hydroamination cyclization (Scheme 1).

\section{Results and Discussion}

To establish the overall best experimental conditions for the synthesis of pyrido/pyrrolo[2,1- $b]$ quinazolin-9 $(1 H)$-ones, we chose 2-(4-pentynyl)-4(3H)-quinazolinone (6A) as a model substrate to prepare them by an intramolecular hydroamination cyclization. The results of these experiments are summarized in
Table 1. Silver trifluoromethanesulfonate (AgOTf) seemed to be the most effective catalyst for this intramolecular hydroamination cyclization (Table 1, entries 1-6), whereas a product was not afforded in the absence of a catalyst (Table 1, entry 7). We also screened different solvents, and the results demonstrated that non-polar aprotic solvents could promote the reaction. Toluene was the most effective solvent for this cyclization (Table 1, entry 3 and entries 8-16). The concentration of the substrate in the reaction mixture also affected the product yield. When the concentration was changed from $0.1 \mathrm{M}$ to $1 \mathrm{M}$, the yield dropped to $82 \%$ (Table 1, entry 17 ). Subsequently, we examined the influence of the reaction temperature, and no better yield could be obtained at a temperature either lower or higher than $80{ }^{\circ} \mathrm{C}$ (Table 1, entries 18 and 19). A prolongation of the reaction time to $12 \mathrm{~h}$ resulted in a slight decrease of the yield (Table 1, entry 20). Performing the reaction without inert gas (argon) atmosphere also led to a decrease of the yield (Table 1, entry 21). In summary, the optimum results were obtained when 2-(4-pentynyl)-4(3H)-quinazolinone $(\mathbf{6 A})$ in toluene was treated with $5 \mathrm{~mol} \%$ of AgOTf in a sealed tube under argon protection at $80{ }^{\circ} \mathrm{C}$ for $3 \mathrm{~h}$ (Table 1, entry 3 ).

To evaluate the scope of the proposed silver-catalyzed intramolecular hydroamination cyclization reaction, we investigated its

\section{Our previous works}

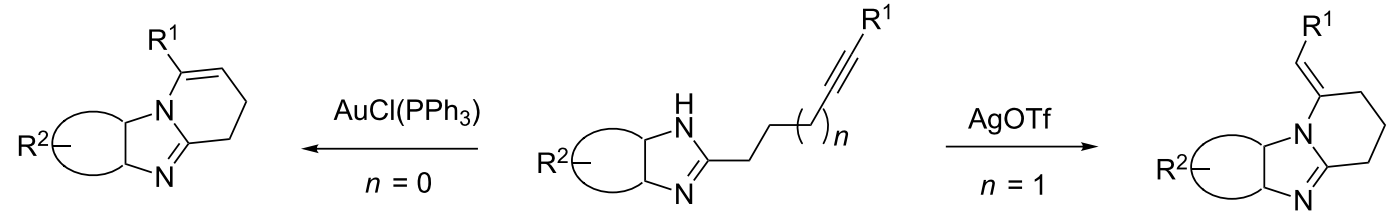

\section{Current work}

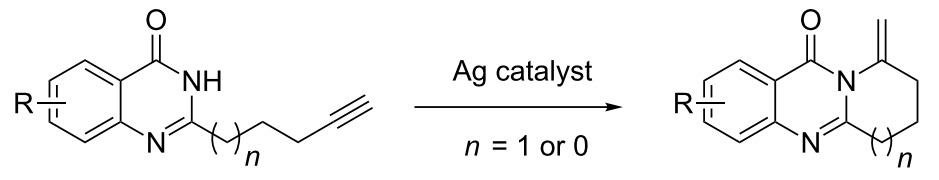


Table 1: Optimization of the reaction conditions. ${ }^{a}$<smiles>C#CCCCc1nc2ccccc2c(=O)[nH]1</smiles>

6A

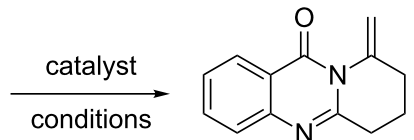

7A

\begin{tabular}{|c|c|c|c|}
\hline Entry & Catalyst & Solvent & Yield (\%) \\
\hline 1 & $\mathrm{AgBF}_{4}$ & toluene & 80 \\
\hline 2 & $\mathrm{AgSbF}_{6}$ & toluene & 62 \\
\hline 3 & AgOTf & toluene & 90 \\
\hline 4 & $\mathrm{AgNO}_{3}$ & toluene & 39 \\
\hline 5 & $\mathrm{AgOCOCF}_{3}$ & toluene & 85 \\
\hline 6 & $\mathrm{AgOAc}$ & toluene & 41 \\
\hline 7 & - & toluene & 0 \\
\hline 8 & AgOTf & 1,2-dichloroethane & 82 \\
\hline 9 & AgOTf & 1,4-dioxane & 70 \\
\hline 10 & AgOTf & DME & 40 \\
\hline 11 & AgOTf & THF & 47 \\
\hline 12 & AgOTf & DMF & 37 \\
\hline 13 & $\mathrm{AgOTf}$ & DMSO & 38 \\
\hline 14 & AgOTf & $\mathrm{MeCN}$ & 73 \\
\hline 15 & AgOTf & $\mathrm{MeOH}$ & 28 \\
\hline 16 & AgOTf & $\mathrm{EtOH}$ & 28 \\
\hline 17 & AgOTf & toluene & $82^{b}$ \\
\hline 18 & AgOTf & toluene & $70^{c}$ \\
\hline 19 & AgOTf & toluene & $83^{d}$ \\
\hline 20 & AgOTf & toluene & $85^{e}$ \\
\hline 21 & AgOTf & toluene & $71^{f}$ \\
\hline
\end{tabular}

${ }^{a} 6 \mathbf{A}(0.2 \mathrm{mmol})$ and catalyst $(5 \mathrm{~mol} \%)$ in the specified solvent $(2 \mathrm{~mL})$ were heated in a sealed vial under argon protection at $80^{\circ} \mathrm{C}$ for $3 \mathrm{~h}$;

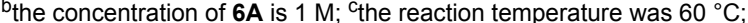

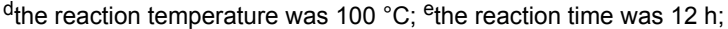

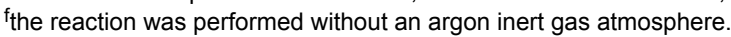

tolerance by probing changes in the substituted 2-(4-pentynyl)$4(3 H)$-quinazolinone $(\mathbf{6 A})$ under the optimum reaction conditions mentioned above (Table 2, entries 1-12). Various substituted 2-(4-pentynyl)-4(3H)-quinazolinones (6A-L) were tolerant of this transformation, and the desired products $7 \mathbf{A}-\mathbf{L}$ were afforded with moderate to excellent yields (53-91\%). It seems that the position and type of substituents on the 2-(4pentynyl)-4(3H)-quinazolinones (6A) only slightly affected the yields of the target compounds (Table 2, entries 1-9). Higher yields could be obtained when the 6- and 7-positions of the 2-(4-pentynyl)-4(3H)-quinazolinone were substituted by methyl and methoxy groups (Table 2, entries 2-4). The introduction of a fluorine, a chlorine and a bromine atom at 5-, 6- and 7-positions resulted in a slight reduction of the yield of the products (Table 2, entries 5-9). However, a bulky phenyl group introduced at the 7-position led to a good yield (Table 2, entry 10). When the benzene ring of the skeleton of the substrate was replaced by a naphthalene ring, the product was obtained at a comparable yield of $87 \%$ (Table 2 , entry 11 ). However, with 2-(4-pentynyl)-thieno[2,3- $d]$ pyrimidin-4(1H)-one (6L) as a substrate, the reaction was significantly different compared to the other substituted 2-(4-pentynyl)-4(3H)-quinazolinones (Table 2, entry 12$)$. Although the thieno analogue $6 \mathbf{L}$ was tolerated in the reaction, the cyclization required substantially longer $(12 \mathrm{~h})$, and the product was obtained in a relatively low yield (only $53 \%)$.

Further studies indicated that 2,3-dihydropyrrolo[2,1-b]quinazolin-9(1H)-ones 9A-L could be generated by the treatment of substituted 2-(3-butynyl)-4(3H)-quinazolinones 8A-L with AgOTf under the optimized reaction conditions. As illustrated in Table 3, 2-(3-butynyl)-4(3H)-quinazolinones 8A-L with

Table 2: Silver-mediated synthesis of target compounds 7A-L. ${ }^{a}$

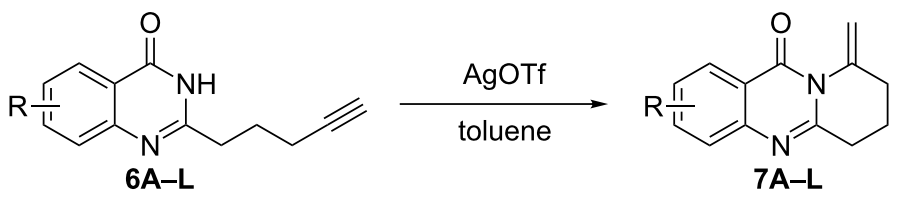

Entry Substrate Product


Table 2: Silver-mediated synthesis of target compounds 7A-L. ${ }^{\text {a }}$ (continued)

3<smiles>C#CCCCc1nc2cc(C)ccc2c(=O)[nH]1</smiles>

4<smiles>C#CCCCc1nc2ccc(OC)cc2c(=O)[nH]1</smiles>

5<smiles>C#CCCCc1nc2cccc(F)c2c(=O)[nH]1</smiles>

6<smiles>C#CCCCc1nc2cccc(Cl)c2c(=O)[nH]1</smiles>

7

8<smiles>C#CCCCc1nc2ccc(Cl)cc2c(=O)[nH]1</smiles><smiles>C#CCCCc1nc2cc(Cl)ccc2c(=O)[nH]1</smiles>

9<smiles>C#CCCCc1nc2ccc(Br)cc2c(=O)[nH]1</smiles>

10<smiles>C#CCCCc1nc2cc(-c3ccccc3)ccc2c(=O)[nH]1</smiles>

11<smiles>C#CCCCc1nc2cc3ccccc3cc2c(=O)[nH]1</smiles>

12

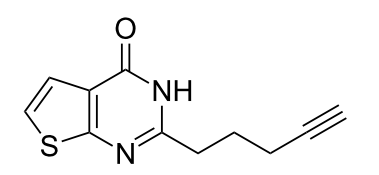<smiles>C=C1CCCc2nc3cc(C)ccc3c(=O)n21</smiles><smiles>C=C1CCCc2nc3ccc(OC)cc3c(=O)n21</smiles>

$7 \mathrm{D}$<smiles>C=C1CCCc2nc3cccc(F)c3c(=O)n2C1=C</smiles><smiles>C=C1CCCc2nc3cccc(Cl)c3c(=O)n21</smiles><smiles>C=C1CCCc2nc3ccc(Cl)cc3c(=O)n21</smiles>

84<smiles>C=C1CCCc2nc3cc(Cl)ccc3c(=O)n21</smiles><smiles>C=C1CCCc2nc3ccc(Br)cc3c(=O)n21</smiles><smiles>C=C1CCCc2nc3cc(-c4ccccc4)ccc3c(=O)n21</smiles><smiles>C=C1CCCc2nc3cc4ccccc4cc3c(=O)n21</smiles><smiles>C=C1CCCc2nc3sccc3c(=O)n21</smiles>

7L

asubstrates $6 \mathrm{~A}-\mathrm{L}(0.4 \mathrm{mmol})$ and catalyst $(5 \mathrm{~mol} \%)$ in anhydrous toluene $(4 \mathrm{~mL})$ were heated in a sealed vial under argon atmosphere at $80{ }^{\circ} \mathrm{C}$ for $3 \mathrm{~h}$; bthe reaction time was $12 \mathrm{~h}$. 
different substituents were well-tolerated in this intramolecular cyclization reaction, and the expected products $9 \mathbf{A}-\mathbf{L}$ were obtained in good to excellent yields ( $80-93 \%$, Table 3, entries $1-12)$.

Based on the results of the present studies, we propose a plausible mechanism for the transformation. As depicted in
Scheme 2, the intramolecular cyclization is initiated by the activation of the terminal alkyne moiety of the substrate with AgOTf to generate the Ag-alkyne $\pi$ complex $\mathbf{I}$ (or its tautomer II). Subsequently, the Ag-alkyne $\pi$ complex I or II is converted into complex III through a nucleophilic attack of the nitrogen atom of the amide, and then produces the final product. Products 7A and 9G were recrystallized and their structures were

Table 3: Silver-mediated synthesis of target compounds 9A-L. ${ }^{a}$<smiles>C#CCCc1nc2cc[R7]cc2c(=O)[nH]1</smiles>

8A-L

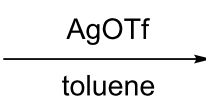<smiles></smiles>

9A-L

\section{Entry} Substrate

Product Yield (\%)

1<smiles>C#CCCc1nc2ccccc2c(=O)[nH]1</smiles>

2<smiles>C#CCCc1nc2ccc(C)cc2c(=O)[nH]1</smiles>

3<smiles>C#CCCc1nc2cc(C)ccc2c(=O)[nH]1</smiles>

4<smiles>C#CCCc1nc2ccc(OC)cc2c(=O)[nH]1</smiles>

5<smiles>C#CCCc1nc2c(OC)cccc2c(=O)[nH]1</smiles>

6<smiles>C#CCCc1nc2cccc(F)c2c(=O)[nH]1</smiles>

7<smiles>C=C1CCc2nc3ccccc3c(=O)n21</smiles><smiles>C=C1CCc2nc3ccc(C)cc3c(=O)n21</smiles>

9B<smiles>C=C1CCc2nc3cc(C)ccc3c(=O)n21</smiles>

9C<smiles>C=C1CCc2nc3ccc(OC)cc3c(=O)n21</smiles>

9D<smiles>C=C1CCc2nc3c(OC)cccc3c(=O)n21</smiles>

9E<smiles>C=C1CCc2nc3cccc(F)c3c(=O)n21</smiles><smiles>C=C1CCc2nc3cccc(Cl)c3c(=O)n21</smiles>

80

90

92<smiles>C#CCCc1nc2cccc(Cl)c2c(=O)[nH]1</smiles> 
Table 3: Silver-mediated synthesis of target compounds 9A-L. ${ }^{a}$ (continued)

8<smiles>C#CCCc1nc2ccc(Cl)cc2c(=O)[nH]1</smiles>

9<smiles>C#CCCc1nc2cc(Cl)ccc2c(=O)[nH]1</smiles>

10<smiles>C#CCCc1nc2ccc(Br)cc2c(=O)[nH]1</smiles>

11

12<smiles>C#CCCc1nc2cc(-c3ccccc3)ccc2c(=O)[nH]1</smiles>

13<smiles>C#CCCc1nc2cc3ccccc3cc2c(=O)[nH]1</smiles><smiles>C#CCCc1nc2sccc2c(=O)[nH]1</smiles><smiles>C=C1CCc2nc3ccc(Cl)cc3c(=O)n21</smiles>

9H<smiles>C=C1CCc2nc3cc(Cl)ccc3c(=O)n21</smiles>

91<smiles>C=C1CCc2nc3ccc(Br)cc3c(=O)n21</smiles>

9J<smiles>C=C1CCc2nc3cc(-c4ccccc4)ccc3c(=O)n21</smiles>

9L<smiles>C=C1CCc2nc3cc4sccc4cc3c(=O)n21</smiles><smiles>C=C1CCc2nc3cc4ccccc4cc3c(=O)n21</smiles>

$9 \mathrm{M}$

a Substrates $8 \mathbf{A}-\mathrm{L}(0.4 \mathrm{mmol})$ and catalyst $(5 \mathrm{~mol} \%)$ in anhydrous toluene $(4 \mathrm{~mL})$ were heated in a sealed vial under argon atmosphere at $80{ }^{\circ} \mathrm{C}$ for $3 \mathrm{~h}$; bthe product could not be isolated due to large amounts of impurities formed during the reaction.

unambiguously confirmed by X-ray diffraction (XRD) studies (see Supporting Information File 1 for details).

\section{Conclusion}

In conclusion, we have developed a chemical methodology for the synthesis of pyrido/pyrrolo[2,1-b]quinazolin-9(1H)-ones through an AgOTf-catalyzed intramolecular alkyne hydroamination cyclization reaction. The methodology is applicable to a wide scope of substrates and generates a series of fused quinazolinone heterocycles in good to excellent yields. It lends itself an alternative method to the construction of innovative molecules with polycyclic architectures. It may be worthwhile to investigate the biological activity of the synthesized structures.

\section{Experimental}

Commercially available reagents and solvents were used without further purification. Column chromatography was performed on silica gel. TLC was performed on silica gel GF254 plates. ${ }^{1} \mathrm{H}$ NMR and ${ }^{13} \mathrm{C}$ NMR spectra were obtained on Varian 300, Bruker 400 and 500 spectrometers. The chemical shifts for ${ }^{1} \mathrm{H}$ NMR were recorded in parts per million (ppm) downfield from tetramethylsilane (TMS) with the residual solvent resonance as the internal standard $\left(7.26 \mathrm{ppm}\right.$ for $\mathrm{CDCl}_{3}$ or $2.50 \mathrm{ppm}$ for DMSO- $d_{6}$ ). The chemical shifts for ${ }^{13} \mathrm{C} \mathrm{NMR}$ were recorded in ppm by using the central peak of $\mathrm{CDCl}_{3}$ (77.23 ppm) or DMSO- $d_{6}$ (39.52 ppm) as the internal standard. Coupling constants $(J)$ are reported in $\mathrm{Hz}$ and refer to apparent peak multiplications. The abbreviations $s, d, t, q, p$ and $m$ stand for singlet, doublet, triplet, quartet, pentet and multiplet, respectively.

General procedure for the synthesis of substrates $6 \mathrm{~A}-6 \mathrm{~L}$ and 8A-8L: To a solution of 5-hexynoic acid $(3.0 \mathrm{mmol})$ in dry $\mathrm{CH}_{2} \mathrm{Cl}_{2}(5 \mathrm{~mL})$ was added EDCI $(3.1 \mathrm{mmol})$ and HOBt ( $3.1 \mathrm{mmol})$. The resulting mixture was stirred at $\mathrm{rt}$ for $2 \mathrm{~h}$. Then 


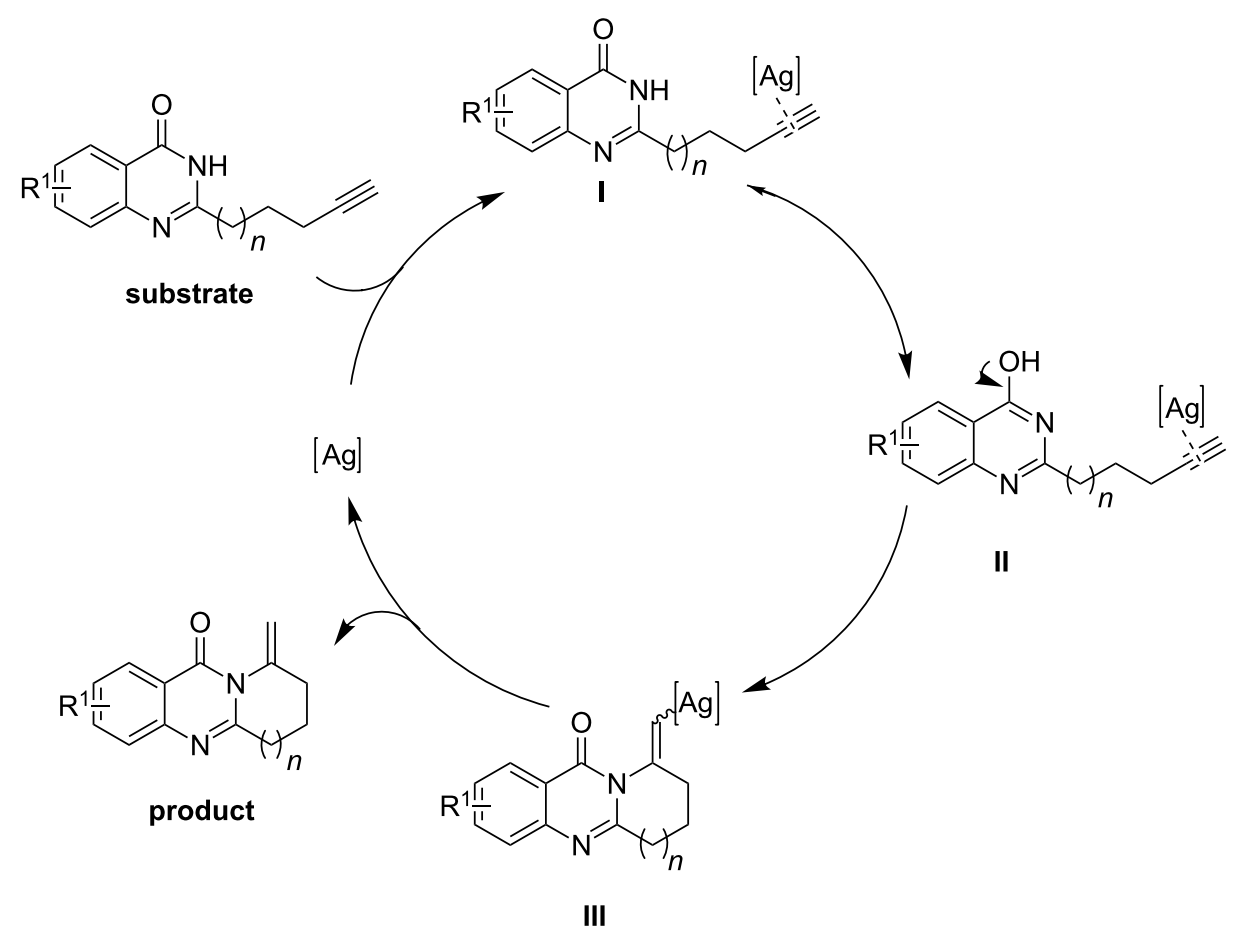

Scheme 2: A plausible mechanism.

substituted or unsubstituted 2-aminobenzamide $(3.0 \mathrm{mmol})$ was added, and the reaction mixture was stirred at $\mathrm{rt}$ for $12 \mathrm{~h}$ while being monitored by TLC. After the addition of $\mathrm{H}_{2} \mathrm{O}(10 \mathrm{~mL})$ the mixture was extracted with ethyl acetate $(3 \times 20 \mathrm{~mL})$. The organic layers were combined and concentrated under vacuum to give the amide intermediate.

The above intermediate was then dissolved in $95 \% \mathrm{EtOH}$ $(5 \mathrm{~mL})$, and solid $\mathrm{NaOH}(6.0 \mathrm{mmol})$ was added. The mixture was heated under reflux for $2 \mathrm{~h}$ while being monitored by TLC. The solvent was evaporated under vacuum. Water $(10 \mathrm{~mL})$ was added, and the mixture was extracted with ethyl acetate $(3 \times 20 \mathrm{~mL})$. The organic layers were combined and dried over anhydrous $\mathrm{Na}_{2} \mathrm{SO}_{4}$. After the removal of the solvent the crude product was purified by silica gel column chromatography with $\mathrm{CH}_{2} \mathrm{Cl}_{2} / \mathrm{MeOH}$ 50:1 (v/v) as an eluent to give the desired substrates $6 \mathbf{A}-\mathbf{6 L}$.

For $\mathbf{8 A - 8 L}$, the same procedure as described above was used, except that 4-pentynoic acid was used instead of 5-hexynoic acid. Compound 6A as an example: ${ }^{1} \mathrm{H}$ NMR $(300 \mathrm{MHz}$, $\left.\mathrm{CDCl}_{3}\right) \delta 11.75(\mathrm{~s}, 1 \mathrm{H}), 8.29(\mathrm{dd}, J=8.0,1.0 \mathrm{~Hz}, 1 \mathrm{H})$, $7.82-7.73(\mathrm{~m}, 1 \mathrm{H}), 7.73-7.66(\mathrm{~m}, 1 \mathrm{H}), 7.52-7.43(\mathrm{~m}, 1 \mathrm{H})$, $2.98-2.88(\mathrm{~m}, 2 \mathrm{H}), 2.41(\mathrm{td}, J=6.9,2.6 \mathrm{~Hz}, 2 \mathrm{H}), 2.21-2.08(\mathrm{~m}$, 2H), $2.01(\mathrm{t}, J=2.6 \mathrm{~Hz}, 1 \mathrm{H}) ;{ }^{13} \mathrm{C}$ NMR $\left(100 \mathrm{MHz}, \mathrm{CDCl}_{3}\right) \delta$ $164.3,155.8,149.4,134.8,127.3,126.5,128.2,120.5,83.2$,
69.4, 34.4, 25.8, 18.0. LRMS (ESI) $m / z: 213[\mathrm{M}+\mathrm{H}]^{+}$; HRMS-ESI $(m / z)$ : $[\mathrm{M}+\mathrm{H}]^{+}$calcd for $\mathrm{C}_{13} \mathrm{H}_{13} \mathrm{~N}_{2} \mathrm{O}, 213.1028$; found, 213.1024 .

General procedure for the synthesis of the target products 7A-7L and 9A-9L: A vial equipped with a magnetic stir bar was charged with the corresponding substrate $6 \mathrm{~A}-6 \mathrm{~L}$ or $8 \mathrm{~A}-\mathbf{8 L}$ (0.4 mmol) and the catalyst AgOTf (5 mol \%) and capped with a septum. The vial was evacuated and backfilled with argon, and this process was repeated three times. Under argon, anhydrous toluene $(4 \mathrm{~mL})$ was injected to the vial with a syringe, and the resulting mixture was stirred at $\mathrm{rt}$ for $10 \mathrm{~min}$. Afterwards, the vial was kept in a preheated oil bath at $80{ }^{\circ} \mathrm{C}$ for the appropriate time. After the reaction was complete, the reaction mixture was cooled to rt and the solvent was evaporated under vacuum. The residue was purified by silica gel column chromatography with petroleum ether/EtOAc 20:1 (v/v) as an eluent to give the desired target compounds 7A-7L and 9A-9L. Compound $7 \mathrm{~A}$ as an example: ${ }^{1} \mathrm{H} \mathrm{NMR}\left(400 \mathrm{MHz}, \mathrm{CDCl}_{3}\right) \delta 8.30$ $(\mathrm{dd}, J=8.0,1.5 \mathrm{~Hz}, 1 \mathrm{H}), 7.82-7.66(\mathrm{~m}, 1 \mathrm{H}), 7.61(\mathrm{~d}, J=8.1$ $\mathrm{Hz}, 1 \mathrm{H}), 7.50-7.37(\mathrm{~m}, 1 \mathrm{H}), 5.58(\mathrm{~s}, 1 \mathrm{H}), 5.45(\mathrm{~s}, 1 \mathrm{H}), 2.84(\mathrm{t}, J$ $=6.9 \mathrm{~Hz}, 2 \mathrm{H}), 2.76-2.56(\mathrm{~m}, 2 \mathrm{H}), 2.00(\mathrm{dt}, J=14.4,7.1 \mathrm{~Hz}$, $2 \mathrm{H}) ;{ }^{13} \mathrm{C} \mathrm{NMR}\left(100 \mathrm{MHz}, \mathrm{CDCl}_{3}\right) \delta 160.3,155.8,146.9,136.9$, 134.4, 127.4, 126.6, 126.5, 121.3, 112.5, 31.8, 29.6, 18.3; LRMS (EI) $m / z: 212[\mathrm{M}]^{+}$; HRMS-EI $(\mathrm{m} / z):[\mathrm{M}]^{+}$calcd for $\mathrm{C}_{13} \mathrm{H}_{12} \mathrm{~N}_{2} \mathrm{O}, 212.0950$; found, 212.0930 . 


\section{Supporting Information}

\section{Supporting Information File 1}

Detailed experimental procedures for all compounds and precursors, copies of ${ }^{1} \mathrm{H} /{ }^{13} \mathrm{C}$ NMR spectra for all compounds.

[http://www.beilstein-journals.org/bjoc/content/ supplementary/1860-5397-11-47-S1.pdf]

\section{Acknowledgements}

We gratefully acknowledge financial support from the National Natural Science Foundation of China Grants (91229204 and 21372235), Major Project of Chinese National Programs for Fundamental Research and Development (2015CB910304), National High Technology Research and Development Program of China (2012AA020302), National Basic Research Program of China (2012CB518005), National S\&T Major Projects (2012ZX09103101-072,2014ZX09507002-001 and 2013ZX09507-001).

\section{References}

1. Michael, J. P. Nat. Prod. Rep. 2004, 21, 650-668. doi:10.1039/b310691h

2. Mhaske, S. B.; Argade, N. P. Tetrahedron 2006, 62, 9787-9826. doi:10.1016/j.tet.2006.07.098

3. Amin, A. H.; Mehta, D. R. Nature 1959, 184, 1317. doi:10.1038/1841317a0

4. Al-Shamma, A.; Drake, S.; Flynn, D. L.; Mitscher, L. A.; Park, Y. H.; Rao, G. S. R.; Simpson, A.; Swayze, J. K.; Veysoglu, T.; Wu, S. T.-S. J. Nat. Prod. 1981, 44, 745-747. doi:10.1021/np50018a025

5. Michael, J. P. Nat. Prod. Rep. 2008, 25, 166-187. doi:10.1039/b612168n

6. Liu, J.-F.; Ye, P.; Sprague, K.; Sargent, K.; Yohannes, D.; Baldino, C. M.; Wilson, C. J.; Ng, S.-C. Org. Lett. 2005, 7, 3363-3366. doi:10.1021/ol0513084

7. Mori, M.; Kobayashi, H.; Kimura, M.; Ban, Y. Heterocycles 1985, 23, 2803-2806. doi:10.3987/R-1985-11-2803

8. Johns, S. R.; Lamberton, J. A. Chem. Commun. 1965, 267 a. doi:10.1039/c1965000267a

9. Kametani, T.; Loc, C. V.; Higa, T.; Koizumi, M.; Ihara, M.; Fukumoto, K. J. Am. Chem. Soc. 1977, 99, 2306-2309. doi:10.1021/ja00449a047

10. Eguchi, S.; Suzuki, T.; Okawa, T.; Matsushita, Y.; Yashima, E.; Okamoto, Y. J. Org. Chem. 1996, 61, 7316-7319. doi:10.1021/jo9609283

11. Mhaske, S. B.; Argade, N. P. J. Org. Chem. 2001, 66, 9038-9040. doi:10.1021/jo010727।

12. Morris, R. C.; Hanford, W. E.; Adams, R. J. Am. Chem. Soc. 1935, 57, 951-954. doi:10.1021/ja01308a052

13. Kametani, T.; Higa, T.; Loc, C. V.; Ihara, M.; Koizumi, M.; Fukumoto, K. J. Am. Chem. Soc. 1976, 98, 6186-6188. doi:10.1021/ja00436a019

14. Severin, R.; Doye, S. Chem. Soc. Rev. 2007, 36, 1407-1420. doi:10.1039/b600981f

15. Müller, T. E.; Hultzsch, K. C.; Yus, M.; Foubelo, F.; Tada, M. Chem. Rev. 2008, 108, 3795-3892. doi:10.1021/cr0306788
16. Alonso, F.; Beletskaya, I. P.; Yus, M. Chem. Rev. 2004, 104, 3079-3160. doi:10.1021/cr0201068

17. Hesp, K. D.; Stradiotto, M. ChemCatChem 2010, 2, 1192-1207. doi:10.1002/cctc.201000102

18. Fürstner, A.; Davies, P. W. Angew. Chem., Int. Ed. 2007, 46, 3410-3449. doi:10.1002/anie.200604335

19. Patil, N. T.; Yamamoto, Y. Chem. Rev. 2008, 108, 3395-3442. doi:10.1021/cr050041j

20. Arcadi, A. Chem. Rev. 2008, 108, 3266-3325. doi:10.1021/cr068435d

21. Wang, Y.; Rapakousiou, A.; Latouche, C.; Daran, J.-C.; Singh, A.; Ledoux-Rak, I.; Ruiz, J.; Saillard, J.-Y.; Astruc, D. Chem. Commun. 2013, 49, 5862-5864. doi:10.1039/c3cc42211a

22. Wong, V. H. L.; Hor, T. S. A.; Hii, K. K. Chem. Commun. 2013, 49, 9272-9274. doi:10.1039/c3cc45500a

23. Patil, N. T.; Singh, V. J. Organomet. Chem. 2011, 696, 419-432. doi:10.1016/j.jorganchem.2010.10.027

24. Kinjo, R.; Donnadieu, B.; Bertrand, G. Angew. Chem., Int. Ed. 2011, 50, 5560-5563. doi:10.1002/anie.201100740

25. McNulty, J.; Keskar, K. Eur. J. Org. Chem. 2014, 1622-1629. doi:10.1002/ejoc.201301368

26. Müller, T. E.; Grosche, M.; Herdtweck, E.; Pleier, A.-K.; Walter, E.; Yan, Y.-K. Organometallics 1999, 19, 170-183. doi:10.1021/om9906013

27. Sevov, C. S.; Zhou, J.; Hartwig, J. F. J. Am. Chem. Soc. 2014, 136, 3200-3207. doi:10.1021/ja412116d

28. Hesp, K. D. Angew. Chem., Int. Ed. 2014, 53, 2034-2036. doi:10.1002/anie.201309262

29. Nguyen, T. M.; Nicewicz, D. A. J. Am. Chem. Soc. 2013, 135, 9588-9591. doi:10.1021/ja4031616

30. Beauchemin, A. M. Org. Biomol. Chem. 2013, 11, 7039-7050. doi:10.1039/c3ob41172a

31. Minatti, A.; Muñiz, K. Chem. Soc. Rev. 2007, 36, 1142-1152. doi:10.1039/b607474j

32. Banerjee, D.; Junge, K.; Beller, M. Angew. Chem., Int. Ed. 2014, 53, 1630-1635. doi:10.1002/anie.201308874

33. Kanno, O.; Kuriyama, W.; Wang, Z. J.; Toste, F. D. Angew. Chem., Int. Ed. 2011, 50, 9919-9922. doi:10.1002/anie.201104076

34. Ye, D.; Zhang, X.; Zhou, Y.; Zhang, D.; Zhang, L.; Wang, H.; Jiang, H.; Liu, H. Adv. Synth. Catal. 2009, 351, 2770-2778. doi:10.1002/adsc.200900505

35. Zhang, X.; Zhou, Y.; Wang, H.; Guo, D.; Ye, D.; Xu, Y.; Jiang, H.; Liu, H. Green Chem. 2011, 13, 397-405. doi:10.1039/C0GC00668H 36. Zhang, X.; Zhou, Y.; Wang, H.; Guo, D.; Ye, D.; Xu, Y.; Jiang, H.; Liu, H. Adv. Synth. Catal. 2011, 353, 1429-1437. doi:10.1002/adsc.201100038 


\section{License and Terms}

This is an Open Access article under the terms of the Creative Commons Attribution License

(http://creativecommons.org/licenses/by/2.0), which permits unrestricted use, distribution, and reproduction in any medium, provided the original work is properly cited.

The license is subject to the Beilstein Journal of Organic Chemistry terms and conditions:

(http://www.beilstein-journals.org/bjoc)

The definitive version of this article is the electronic one which can be found at:

doi:10.3762/bjoc. 11.47 